\title{
LEAF SENESCENCE OF COMMON BEAN PLANTS AS AFFECTED BY SOIL PHOSPHORUS SUPPLY(1)
}

\author{
Adelson Paulo Araújo( ${ }^{(2)}$, Flavio Yuudi Kubota ${ }^{(3)} \&$ Marcelo \\ Grandi Teixeira $^{(4)}$
}

\begin{abstract}
SUMMARY
Responses of leaf senescence to $P$ supply could constitute adaptive mechanisms for plant growth under P-limiting conditions. The aim of this study was to evaluate the effects of soil $P$ supply on leaf senescence of common bean (Phaseolus vulgaris L.). Eight $P$ levels, ranging from 5 to $640 \mathrm{mg} \mathrm{kg}^{-1} \mathrm{P}$, were applied to pots containing four bean plants of cultivar Carioca in $10 \mathrm{~kg}$ of an Oxic Haplustult soil. Attached leaves were counted weekly, abscised leaves were collected every other day, and seeds were harvested at maturity. The number of live leaves increased until 48 days after emergence (DAE) and decreased afterwards, irrespective of applied $P$ levels. At lower applied $P$ levels, the initial increase and the final decrease of leaf number was weak, whereas at higher applied $P$ levels the leaf number increased intensively at the beginning of the growth cycle and decreased strongly after 48 DAE. Dry matter and $P$ accumulated in senesced leaves increased as soil $P$ levels increased until 61 DAE, but differences between $P$ treatments narrowed thereafter. The greatest amounts of dry mass and $P$ deposited by senesced leaves were observed at 48-54 DAE for high P levels, at 62-68 DAE for intermediate $P$ levels and at 69-76 DAE for low $P$ levels. These results indicate that soil $P$ supply did not affect the stage of maximal leaf number and the beginning of leaf senescence of common bean plants, but the stage of greatest deposition of senesced leaves occurred earlier in the growth cycle as the soil $\mathbf{P}$ supply was raised.
\end{abstract}

Index terms: growth, harvest index, ontogeny, Phaseolus vulgaris.

\footnotetext{
(1) Recebido para publicação em abril de 2006 e aprovado em fevereiro de 2007.

(2) Professor do Departamento de Solos, Universidade Federal Rural do Rio de Janeiro - UFRRJ. CEP 23890-000 Seropédica (RJ). Bolsista do CNPq. E-mail: aparaujo@ufrrj.br

(3) Engenheiro-Agrônomo do Instituto Nacional de Colonização e Reforma Agrária - INCRA. Rua 08, Quadra 15 - CPA, CEP 78050 970 Cuiabá (MT). E-mail: kubota@incra.gov.br

(4) Pesquisador da Embrapa Agrobiologia. CEP 23890-000 Seropédica (RJ). E-mail: grandi@cnpab.embrapa.br
} 


\title{
RESUMO: SENESCÊNCIA FOLIAR DO FEIJOEIRO AFETADA PELO SUPRIMENTO DE FÓSFORO NO SOLO
}

\begin{abstract}
As respostas da senescência foliar ao suprimento de $P$ podem constituir estratégias adaptativas para o crescimento vegetal sob condições limitantes do nutriente. O objetivo deste trabalho foi avaliar os efeitos do suprimento de $P$ no solo na senescência foliar do feijoeiro (Phaseolus vulgaris L.). Oito doses de $P$, variando entre 5 e $640 \mathrm{mg} \mathrm{kg}^{-1} \mathrm{de} P$, foram aplicadas em vasos com $10 \mathrm{~kg}$ de Argissolo Óxico, onde foram crescidas quatro plantas da cultivar Carioca. As folhas presas às plantas foram contadas semanalmente; as folhas senescidas, coletadas em intervalos de dois dias; e as sementes colhidas na maturação. $O$ número de folhas vivas aumentou até 48 dias após emergência (DAE) e decresceu após, independentemente da dose de $P$ aplicada ao solo. Nas doses mais baixas de $P$, o aumento inicial e o decréscimo final do número de folhas foram pouco intensos, enquanto nas maiores doses desse nutriente o número de folhas aumentou intensamente no início e decresceu rapidamente após $48 \mathrm{DAE}$. A acumulação de massa seca e de $P$ nas folhas senescentes aumentou com o acréscimo das doses de nutriente até 61 DAE; posteriormente, reduziram-se as diferenças entre as doses de $P$. As maiores quantidades de massa seca e de $P$ depositadas pelas folhas senescentes foram observadas aos 48 54 DAE nas maiores doses de $P$; aos 62-68 DAE, nas doses intermediárias; e aos 69$76 \mathrm{DAE}$, nas menores doses. Os resultados indicam que o suprimento de $P$ no solo não afetou o estádio de máximo número de folhas e o início da senescência foliar de plantas de feijoeiro; contudo, o estádio de máxima deposição de folhas senescentes ocorreu mais cedo durante o ciclo de crescimento com o aumento do suprimento de P no solo.
\end{abstract}

Termos de indexação: crescimento, folha, índice de colheita, ontogenia, Phaseolus vulgaris.

\section{INTRODUCTION}

Leaf senescence can be defined as the orderly degradation of cell constituents in the leaf, which allows the plants to remobilize the materials released during this process from leaves to reproductive organs (Huffaker, 1990). Leaf senescence can be genetically controlled to occur at a given time in the leaf lifespan, even when growth conditions are optimal, but it can also be environmentally induced, when inputs such as water and nutrients are restricted (Huffaker, 1990). Leaf maturity and senescence are associated with biochemical changes such as rapid degradation of ribosomes and rRNA, a moderately rapid breakdown of total protein, and gradual followed by accelerated chlorophyll degradation (Makrides \& Goldthwaite, 1981).

One adaptive value of leaf senescence and its concomitant degradation of leaf macromolecules is the recovery of mobile growth-limiting nutrients such as $\mathrm{N}$ and $\mathrm{P}$, enabling plants to re-use these nutrients for further growth (Aerts, 1996). Hydrolysis of nucleic acids and phospholipids contributed to 40-47 and 26$38 \%$, respectively, of the total $\mathrm{P}$ resorbed from senescing leaves of deciduous species (Aerts, 1996). In field-grown common bean a significant proportion of seed $\mathrm{N}$ demand was met by translocation from leaves (Lynch \& White, 1992); more than half of the $\mathrm{P}$ demand of pods and seeds of common bean grown in pots was supplied by leaf remobilization (Snapp \& Lynch, 1996). However, such leaf nutrient depletion could limit the late-season canopy photosynthesis in leguminous crops, indicating that delaying leaf senescence in order to extend the seed-filling period would be a strategy for increasing grain yield (Grabau et al., 1986; Lynch \& Rodriguez, 1994). Nevertheless, soybean progeny lines showed an inverse relationship between grain yield and delayed leaf senescence, suggesting that maximum yields can only be achieved in plants whose leaves senesce during pod-filling (Phillips et al., 1984). Therefore, crop improvement should balance the extension of the mature phase of canopy as a carbon source and the rapid recovery of mineral nutrients during leaf senescence (Thomas \& Stoddart, 1980).

A profound understanding of the factors that control leaf senescence and nutrient resorption is lacking, and their relationship to the plant nutrient status is yet unclear (Franklin \& Agren, 2002). The is levels to which $\mathrm{N}$ and $\mathrm{P}$ were reduced in senesced leaves were significantly correlated in woody perennials, denoting that selection for final concentrations is senesced leaves was similar for both nutrients (Killingbeck, 1996). Induction of $\mathrm{P}$ deficiency during soybean seed development antecipitated the senescence process compared with an optimal $\mathrm{P}$ supply, probably due to altered $\mathrm{C}$ partitioning in leaves (Grabau et al., 1986). On the other hand, enhanced soybean leaf $\mathrm{P}$ concentration prevented net $\mathrm{P}$ remobilization but did not alter leaf senescence (CraftsBrandner, 1992), and foliar nutrient application that increased $\mathrm{N}$ and $\mathrm{P}$ concentration in soybean leaves failed to delay the beginning of senescence (Sesay \& Shibles, 1980), suggesting that leaf $\mathrm{P}$ status does not 
exert any regulatory control over leaf senescence. Patterns of $\mathrm{P}$ mobilization were similar in common bean plants under low or high soil $\mathrm{P}$ supply, although the period of higher rates of $\mathrm{P}$ loss from leaves and stems differed between P-treatments (Snapp \& Lynch, 1996).

Killingbeck (1996) proposed that the nutrient resorption during leaf senescence should be expressed in terms of the percent reduction between green and senesced leaves (resorption efficiency) or the terminal concentration in senesced leaves (resorption proficiency). Proficiency values appeared to be a more objective measure of the degree to which selection had minimized nutrient loss, but the understanding whether resorption proficiency is a function of soil fertility remains incomplete (Killingbeck, 1996). Differential responses of leaf senescence and nutrient resorption to $\mathrm{P}$ availability could constitute adaptive mechanisms for growth under P-limiting conditions which prevails in tropical soils. The employment of a wider variation of soil $\mathrm{P}$ supplies than the relatively few $\mathrm{P}$ treatments used in previous studies on leaf senescence of leguminous plants (Grabau et al., 1986; Crafts-Brandner, 1992; Snapp \& Lynch, 1996) may contribute to elucidate this issue. This work had the objective to evaluate the effects of varied soil $\mathrm{P}$ supply on leaf senescence of common bean (Phaseolus vulgaris L.) plants.

\section{MATERIAL AND METHODS}

The experiment was carried at the National Research Center in Agrobiology (Embrapa Agrobiologia, Seropédica, Brazil), from November 2001 to January 2002. The substrate for the pot plants was a $6 \mathrm{~mm}$-sieved surface soil (A horizon of an Oxic Haplustult), with water $\mathrm{pH}$ of $4.5,1 \mathrm{mg} \mathrm{kg}^{-1}$ available $\mathrm{P}$ (Mehlich-1), $0.5 \mathrm{cmol}_{\mathrm{c}} \mathrm{L}^{-1}$ extractable Al, $0.8 \mathrm{cmol}_{\mathrm{c}} \mathrm{L}^{-1}$ extractable $\mathrm{Ca}+\mathrm{Mg}$, and sandy clay loam texture (Embrapa, 1997). Eight P levels were applied to the soil: 5, 10, 20, 40, 80, 160, 320, and $640 \mathrm{mg} \mathrm{kg}^{-1}$ $\mathrm{P}$, named $\mathrm{P} 1, \mathrm{P} 2, \mathrm{P} 3, \mathrm{P} 4, \mathrm{P} 5, \mathrm{P} 6, \mathrm{P} 7$, and $\mathrm{P} 8$, respectively. Owing to the low soil fertility and the expected larger experimental error at low soil $\mathrm{P}$ levels, the number of replicates per treatment was raised as the applied P level decreased: 24 pots for the two lowest P levels, 16 pots for the intermediate levels, and 8 pots for the three highest levels, totaling 120 pots; the replications were divided in four experimental blocks.

Each pot contained $10 \mathrm{~kg}$ of soil limed with $500 \mathrm{mg} \mathrm{kg}^{-1} \mathrm{CaCO}_{3}$ and $50 \mathrm{mg} \mathrm{kg}^{-1} \mathrm{MgCO}_{3}$. Twenty days later each pot received nutrients at the following levels (in mg kg-1 soil): $30 \mathrm{~N}$ as $\left(\mathrm{NH}_{4}\right)_{2} \mathrm{SO}_{4} ; 10 \mathrm{Mg}$ as $\mathrm{MgSO}_{4} .7 \mathrm{H}_{2} \mathrm{O} ; 2 \mathrm{Cu}$ as $\mathrm{CuSO}_{4} .5 \mathrm{H}_{2} \mathrm{O} ; 1 \mathrm{Zn}$ as $\mathrm{ZnSO}_{4} .7 \mathrm{H}_{2} \mathrm{O} ; 0.1 \mathrm{~B}$ as $\mathrm{H}_{3} \mathrm{BO}_{3} ; 0.2 \mathrm{Mo}$ as $\mathrm{Na}_{2} \mathrm{MoO}_{4} .2 \mathrm{H}_{2} \mathrm{O}$; $1 \mathrm{Fe}$ as Fe-EDTA; and the P levels of each treatment as $\mathrm{KH}_{2} \mathrm{PO}_{4}$. At the lower $\mathrm{P}$ levels, $\mathrm{KCl}$ was applied to equalize the $\mathrm{K}$ supply with the $160 \mathrm{mg} \mathrm{kg}^{-1}$
P-treatment. At sowing, the soil water $\mathrm{pH}$ in the pots was 5.3 and levels of available P (Mehlich-1) of 1, 2, 3, $6,14,32,75$, and $190 \mathrm{mg} \mathrm{kg}^{-1} \mathrm{P}$, respectively for the applied P levels of $5,10,20,40,80,160,320$, and $640 \mathrm{mg} \mathrm{kg}^{-1} \mathrm{P}$. Four plants of cultivar Carioca, considered as a source of genetic adaptation to low $\mathrm{P}$ soils (Lynch \& Van Beem, 1993; Araújo \& Teixeira, 2000), were grown per pot after thinning. Pots were placed in the open air on tiles on a sward, spaced $1 \mathrm{~m}$, and irrigated whenever necessary. Plants were staked due to the indeterminate growth habit of cultivar Carioca. Each pot received $400 \mathrm{mg} \mathrm{N}$ as $\left(\mathrm{NH}_{4}\right)_{2} \mathrm{SO}_{4}$, split in two applications, 20 and 35 days after emergence (DAE). During the experiment, the mean temperature was $24.6{ }^{\circ} \mathrm{C}$ and average relative humidity $75 \%$.

Live leaves, considered as the fully expanded trifoliate leaves attached to plants, were counted weekly after 20 DAE. From 34 DAE onwards, senesced leaves, determined as the abscised leaves, were collected every other day. The material of each week was grouped, oven-dried, weighed and ground. At maturity, stems and pods were harvested and pods threshed. Stems, pod walls and seeds were dried, weighed and ground. In each plant portion, including senesced leaves collected per week, the $\mathrm{P}$ concentration was measured by nitro-perchloric digestion and molybdenum-ascorbic acid colorimetric dosage (Embrapa, 1997). Senesced leaves collected between 34 and 47 DAE were bulked per pot for $\mathrm{P}$ analysis due to their small mass. Phosphorus accumulated in each plant portion was obtained by the product of $\mathrm{P}$ concentration and dry mass. The harvest index was calculated as the ratio between seed and above-ground dry mass (seeds plus stems and pod-walls) at maturity, and $\mathrm{P}$ harvest index as the ratio between $\mathrm{P}$ accumulated in seeds and in above-ground biomass at maturity.

Analysis of variance was performed separately for each harvest, based on a randomized block design with different numbers of replicates per treatment, considering the effects of soil P levels (Neter et al., 1990). Means were compared in pairs by Tukey's test. To improve the visualization of figures, some similar $\mathrm{P}$ levels were grouped and an averaged least significance difference was calculated. Some data were adjusted by multiple regression to the logarithmic model, $\mathrm{y}=\mathrm{a}+\mathrm{b} \ln (\mathrm{x})$, where $\mathrm{y}$ is the dependent variable, and $\mathrm{x}$ the $\mathrm{P}$ levels applied to the soil (Neter et al., 1990). This model was chosen for its higher coefficient of determination $\left(\mathrm{R}^{2}\right)$, compared to other statistical models, and owing to the biological significance for this work.

\section{RESULTS}

The growth response of bean plants to the different $\mathrm{P}$ levels applied to the low fertility soil varied 
considerably (Figure 1). Flowering occurred approximately at 40 days after emergence (DAE) in most pots. Between 20 and $48 \mathrm{DAE}$, leaf number increased as the applied P level increased (Figure 1), indicating that leaf production responded intensively to $\mathrm{P}$ supply. However, after 55 DAE the responses of leaf number to increased $\mathrm{P}$ levels were less intense, and in the end of the experiment the leaf number did not differ significantly between treatments (Figure 1).

At every $\mathrm{P}$ level applied to the soil, the number of live leaves increased until $48 \mathrm{DAE}$ and decreased thereafter; leaf number increased intensively between 34 and 41 DAE (Figure 1). Soil P supply affected the speed of leaf appearance and decay. At the highest $\mathrm{P}$ levels applied to the soil (P5 to P8), leaf number increased intensively in the beginning of the growth cycle but dropped drastically after 48 DAE (Figure 1). At intermediate applied P levels (P3 and P4), leaf number decreased slowly between 48 and $62 \mathrm{DAE}$ and dropped after 62 DAE. At the lower applied P levels (P1 and P2), leaf number increased slowly until $48 \mathrm{DAE}$ and decreased slowly thereafter. Notably, the experimental error of leaf number increased as plants aged (Figure 1).

Since the first week of leaf abscission until $61 \mathrm{DAE}$, bean plants grown at higher $\mathrm{P}$ levels applied to the soil (P7 and P8) produced more senesced leaf mass than plants grown at intermediate $\mathrm{P}$ levels ( $\mathrm{P} 5$ and P6), and plants at intermediate P levels had more senesced leaves than plants at low P levels (P1 to P4) (Figure 2). The mass of senesced leaves was however highest at 62-68 DAE at P3 and P4 levels, and at 69-76 DAE the plants grown at P2, P3 and P4 levels produced more senesced leaves than plants at $\mathrm{P} 5$ and P6 levels (Figure 2). Different effects of P supply on

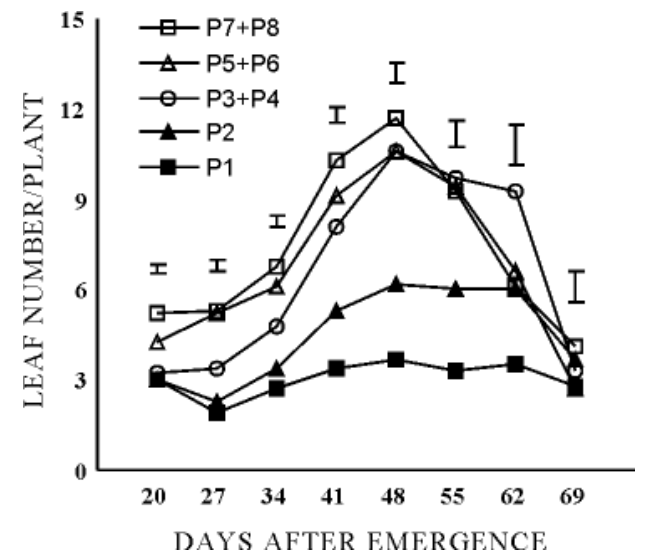

Figure 1. Number of live trifoliate leaves during the growth cycle of common bean plants grown at eight $P$ levels applied to the soil (in $\mathrm{mg} \mathrm{kg}^{-1} \mathrm{P}$ ): P1 5, P2 10, P3 20, P4 40, P5 80, P6 160, P7 320 P8 640; some $P$ levels were grouped. Vertical bars represent the least significant difference (Tukey test at 0.05 significance level), and compare $P$ levels within each day. leaf abscission were also evident. At P1 and P2 levels, the mass of senesced leaves increased after $61 \mathrm{DAE}$, and at P3 and P4 levels the mass of senesced leaves was highest at 62-68 DAE, when the number of live leaves decreased drastically (Figure 1). At P5 to P8 levels, the mass of senesced leaves increased until 4854 DAE and decreased continuously afterwards (Figure 2).

During the whole experiment the amount of $\mathrm{P}$ in senesced leaves was lowest at P1 and P2 levels (Figure 2). Between 34 and 54 DAE, $\mathrm{P}$ accumulated in senesced leaves was higher at P7 and P8 levels than at P5 and P6 levels, and higher at P5 and P6 levels than at P3 and P4 levels. P accumulated in senesced leaves at 55 DAE did not differ between P5 to P8 levels, and at 62-68 DAE leaf P accumulated was similar between P3 to P8 levels. Time variation of $\mathrm{P}$ accumulation in senesced leaves differed from biomass accumulation. $\mathrm{P}$ accumulated in senesced leaves was highest at 48-45 DAE for P7 and P8 levels, at 55-61 DAE for P5 and P6 levels, at 62-68 DAE for $\mathrm{P} 3$ and $\mathrm{P} 4$ levels, and in the last week for P1 and P2 levels (Figure 2).
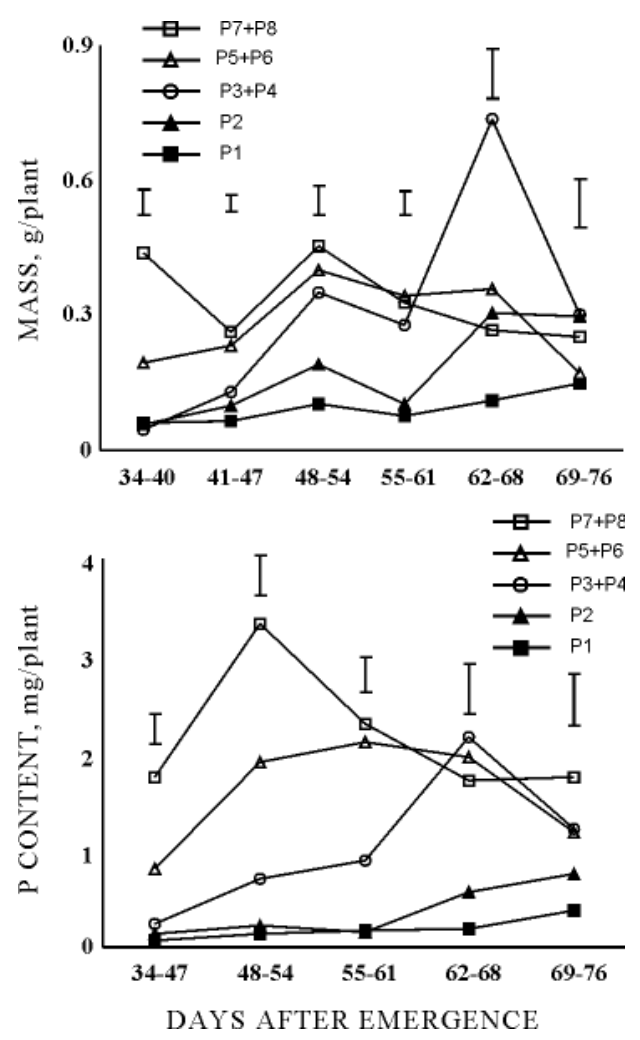

Figure 2. Mass and $P$ accumulated in senesced leaves at each week of growth, of common bean plants grown at eight $P$ levels applied to the soil (in mg kg-1 P): P1 5, P2 10, P3 20, P4 40, P5 80, P6 160, P7 320 P8 640; some P levels were grouped. Vertical bars represent the least significant difference (Tukey test at 0.05 ), and compare $P$ levels within each week. 
Phosphorus concentration in senesced leaves increased as the applied $\mathrm{P}$ level increased, responding intensively to P supply (Figure 3). Senesced leaf P concentrations were always lowest for applied $\mathrm{P}$ levels P1 and P2 and highest for P8 level. There was an overall trend of increasing leaf $\mathrm{P}$ concentration in senesced leaves as plants aged (Figure 3).

Figure 4 presents the proportions of mass and $\mathrm{P}$ accumulated in senesced leaves in each week of growth, compared to the total accumulation of the entire growth cycle. At lower applied P levels (P1 and P2), major proportions of mass and $\mathrm{P}$ accumulated in senesced leaves were observed at the end of the growth cycle, whereas at intermediate $\mathrm{P}$ levels (P3 and $\mathrm{P} 4)$ major proportions were observed at 62 to $68 \mathrm{DAE}$ (Figure 4). For P6 level, major proportions of mass and $\mathrm{P}$ accumulated in senesced leaves were observed at 48-54 DAE. For P7 and P8 levels, maximal proportions of mass and $\mathrm{P}$ accumulated in senesced leaves were not synchronous, at 34-40 DAE for mass and at 48-54 DAE for P (Figure 4). Therefore, as P levels applied to the soil increased, the stage of greatest proportion of mass and $\mathrm{P}$ deposited by senesced leaves occurred earlier in the growth cycle of bean plants.

The logarithmic model adjusted to data of biomass in plant portions at maturity and in senesced leaves summed up across the experiment, indicates a strong response of plant growth as applied $\mathrm{P}$ level increased up to $40 \mathrm{mg} \mathrm{kg}^{-1} \mathrm{P}$, and smaller growth increments between 80 and $640 \mathrm{mg} \mathrm{kg}^{-1} \mathrm{P}$ (Figure 5). This model further indicates that the maximum plant growth was not reached in this experiment even at the highest $\mathrm{P}$ level applied to the soil, but additional biomass

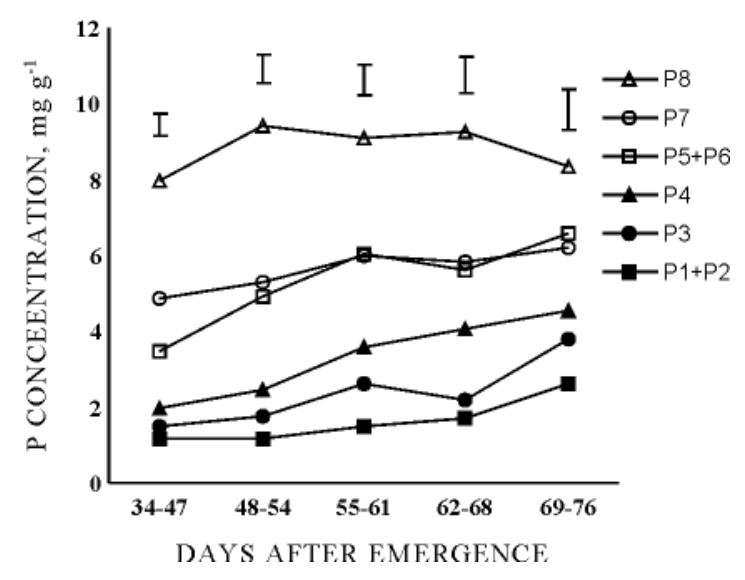

Figure 3. Phosphorus concentration in senesced leaves during the growth cycle of common bean plants grown at eight $P$ levels applied to the soil (in $\mathrm{mg} \mathrm{kg}^{-1} \mathrm{P}$ ): P1 5, P2 10, P3 20, P4 40, P5 80, P6 160, P7 320 P8 640; some $P$ levels were grouped. Vertical bars represent the least significant difference (Tukey test at 0.05 ), and compare $P$ levels within each week.
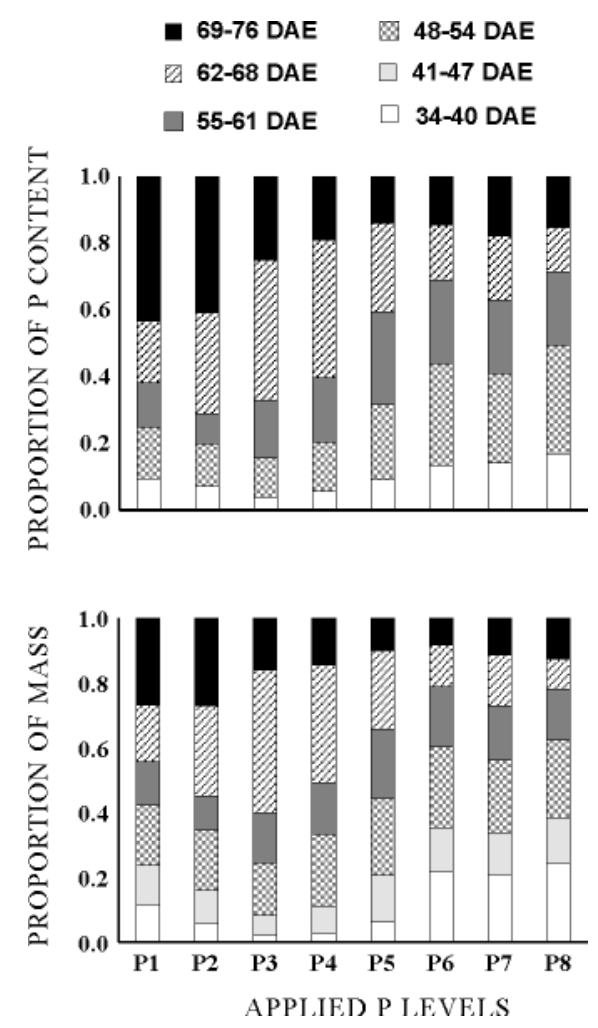

Figure 4. Proportion of dry mass and $P$ accumulated in senesced leaves at each week of growth, relative to total dry mass and $P$ accumulated in senesced leaves throughout the growth cycle, of common bean plants grown at eight $P$ levels applied to the soil (in $\mathrm{mg} \mathrm{kg}^{-1} \mathrm{P}$ ): P1 5, P2 10, P3 20, P4 40, P5 80, P6 160, P7 320 P8 640; DAE: days after emergence.

increases could only be achieved by higher amounts of $\mathrm{P}$ application. Phosphorus accumulated in senesced leaves, stems, and pod walls showed a similar pattern, but values were highest throughout at the applied $\mathrm{P}$ level of $640 \mathrm{mg} \mathrm{kg}^{-1} \mathrm{P}$ (Figure 5).

Seed $\mathrm{P}$ concentration varied between 3.0 and $5.4 \mathrm{mg} \mathrm{g}^{-1} \mathrm{P}$ (Table 1), similar to the range observed by Teixeira et al. (1999) for cultivar Carioca at different levels of soil $\mathrm{P}$ supply, i.e., from 2.6 to $5.1 \mathrm{mg} \mathrm{g}^{-1} \mathrm{P}$. The logarithmic model indicates that grain $\mathrm{P}$ concentration responded to applied $\mathrm{P}$ levels, with increases in $\mathrm{P}$ concentration as $\mathrm{P}$ level increased up to $40 \mathrm{mg} \mathrm{kg}^{-1} \mathrm{P}$, and a relative stability between levels of 40 and $640 \mathrm{mg} \mathrm{kg}^{-1} \mathrm{P}$. In spite of differences among P levels applied to the soil for accumulation of biomass and $\mathrm{P}$ (Figure 5), the adjustment of the logarithmic model was little significant for data of the harvest index and not significant for data of $\mathrm{P}$ harvest index, indicating that these indices did not differ among applied P levels, despite the smaller harvest index at the lowest applied P level (Table 1). 

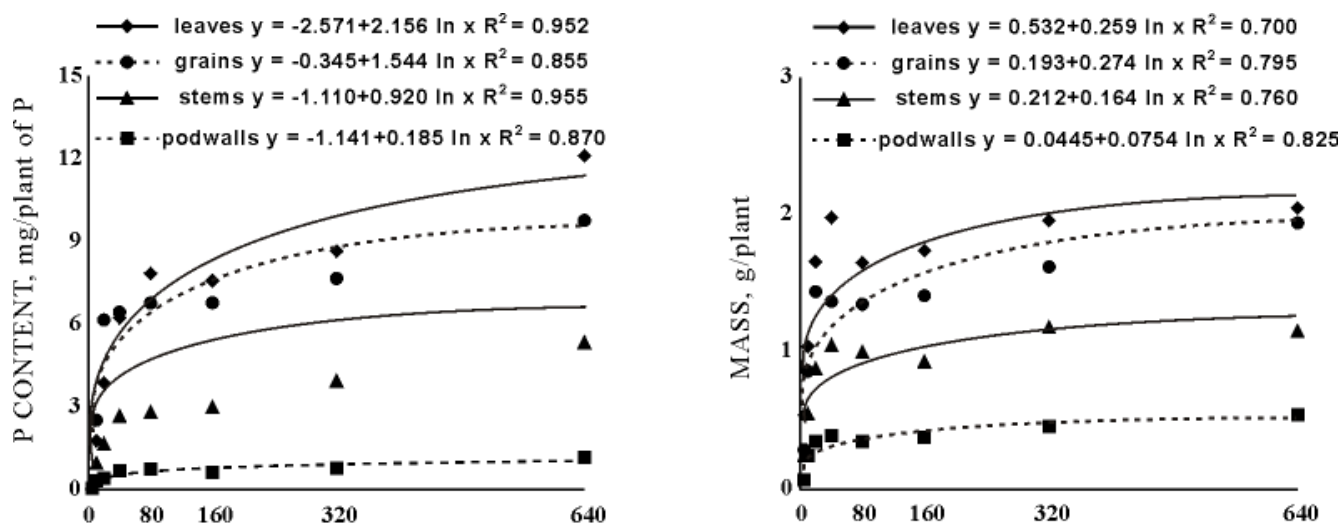

APPLIED P LEVELS, $\mathrm{mg} \mathrm{kg}^{-1}$ of $\mathrm{P}$

Figure 5. Dry mass and $P$ accumulated in stems, pod walls and grains at maturity, and in senesced leaves totalized throughout the growth cycle, of common bean plants grown at eight $P$ levels applied to the soil; points represent the experimental means, and lines the logarithmic model adjusted to the data.

Table 1. Harvest index (ratio between seed and above-ground dry mass), $P$ harvest index (ratio between $P$ content in seed and in above-ground biomass), and grain $P$ concentration at maturity, of common bean plants grown at eight $P$ levels applied to the soil

\begin{tabular}{cccc}
\hline Applied P levels & Harvest index & P harvest index & Grain P concentration \\
\hline $\mathrm{mg} \mathrm{kg}^{-1} \mathrm{P}$ & $\mathrm{g} \mathrm{g}^{-1}$ & $\mathrm{~g} \mathrm{P} \mathrm{g}^{-1} \mathrm{P}$ & $\mathrm{mg} \mathrm{g}^{-1} \mathrm{P}^{-1}$ \\
5 & 0.41 & 0.60 & 3.0 \\
10 & 0.48 & 0.65 & 3.2 \\
20 & 0.48 & 0.69 & 3.9 \\
40 & 0.47 & 0.62 & 5.0 \\
80 & 0.48 & 0.66 & 5.1 \\
160 & 0.51 & 0.66 & 4.9 \\
320 & 0.47 & 0.60 & 5.0 \\
640 & 0.51 & 0.60 & 5.4 \\
$\mathrm{R}^{2(1)}$ & $0.57^{*}$ & 0.05 & $0.82^{* * *}$ \\
\hline
\end{tabular}

(1) Coefficient of determination of the logarithmic model adjusted to data of each trait considering $\mathrm{P}$ levels as independent variable; ${ }^{*}, * * *$ significant at 5 and 0.1 levels by the $\mathrm{F}$ test.

\section{DISCUSSION}

Leaf abscission, particularly of primary leaves, was initiated approximately at 34 days after emergence (DAE) (Figure 2), i.e., before full flowering at about 40 DAE. Even in the growth stages of increasing number of live leaves, between 34 and 48 DAE (Figure 1), leaf decay was already going on (Figure 2). Under field conditions, the maximal leaf area index of cultivar Carioca was observed at 40 DAE (Lima et al., 2005). This denotes that the maximum production of biomass of a common bean plant can not be defined only by the standing shoot biomass, since even in the stages of intense growth there is a loss of leaf mass through abscission. At the beginning of pod filling, near 48 DAE, live leaf number decreased rapidly and leaf decay increased regardless of $\mathrm{P}$ treatments (Figures 1 and 2), indicating that the promotion of leaf senescence was mainly induced by developing seeds. Similarly, soybean plants with different leaf nutrient concentrations promoted by foliar sprays began leaf senescence simultaneously, shortly after the beginning of rapid seed growth (Sesay \& Shibles, 1980).

These results indicate that $\mathrm{P}$ nutrition did not affect the stage of maximal leaf number and the beginning of leaf senescence (Figure 1). However, the speed of the process of leaf appearance and abscission 
was altered by soil $\mathrm{P}$ availability. Enhanced P nutrition stimulated the production of new leaves, resulting in increased leaf number as the applied $\mathrm{P}$ level was raised until mid- pod filling (Figure 1). However, in later growth stages, differences among applied $\mathrm{P}$ levels for leaf number narrowed due to the intense leaf decay at high $\mathrm{P}$ levels, as observed in field-grown common bean by Manrique (1986). Stone \& Pereira (1994) noticed that two different fertilizer levels did not affect the time of maximum leaf area index of field-grown common bean cultivars, but plants at high fertilizer rate reached a higher maximum leaf area index and the decrease in leaf area thereafter was faster until maturity.

Although leaf decay was mainly induced by pod filling irrespective of soil $\mathrm{P}$ levels (Figures 1 and 2), soil $\mathrm{P}$ supply did affect the speed of leaf senescence. The greatest amounts of mass and $\mathrm{P}$ deposited by senesced leaves (Figure 2), and also the largest proportions of mass and $\mathrm{P}$ accumulated in each week of growth as related to the total accumulation during the growth cycle (Figure 4), were observed at 48-54 DAE for high $\mathrm{P}$ levels (P5 to P8), at 62-68 DAE for intermediate $\mathrm{P}$ levels (P3 and P4) and at 69-76 DAE for low P levels (P1 and P2). This indicates that plants under $\mathrm{P}$ deficiency had a slow leaf growth and tended to retain their few leaves, whereas plants under high $\mathrm{P}$ supply had increased leaf appearance but also advanced leaf abscission. Indeed, bean plants under $\mathrm{P}$ deficiency are able to modify the photosynthetic metabolism to enhance $\mathrm{P}$ recirculation in order to maintain adequate photosynthetic rates (Kondracka \& Rychter, 1997).

The $\mathrm{P}$ concentration in senesced leaves expresses the proficiency of nutrient resorption from senescing leaves to growing tissues (Killingbeck, 1996), which was reduced as soil $P$ availability increased (Figure 3). At higher applied $\mathrm{P}$ levels, a larger amount of $\mathrm{P}$ was not translocated to seeds, resulting in little increments in final seed $\mathrm{P}$ concentrations (Table 1) and high $\mathrm{P}$ concentrations in senesced leaves (Figure 3 ). Since P concentration in senesced leaves tended to increase as plants aged (Figure 3), resorption proficiency was reduced with plant ontogeny. As leaf senescence implies in cellular proteolytic activity (Huffaker, 1990), it is expected that the efficacy of nutrient translocation from senescing leaves is reduced as plants mature. Additionally, during the final stages of seed maturity, the sink strength for nutrients resorbed from leaves would be weakened, since maximal $\mathrm{P}$ translocation from leaves occurs during the stages of grain development, after which the export from leaves usually declines (Mondal \& Choudhuri, 1985). Values of $\mathrm{P}$ concentration in senesced leaves (Figure 3) were much higher than those reported for Aerts (1996) in forb species (average $1.9 \mathrm{mg} \mathrm{g}^{-1} \mathrm{P}$ ), probably indicating low resorption proficiency in common bean.

In spite of the improved leaf growth of bean plants by increased P levels applied to the soil (Figure 1), which resulted in larger accumulation of biomass and $\mathrm{P}$ at maturity at higher applied $\mathrm{P}$ levels (Figure 5), harvest indices did not respond to increased applied $\mathrm{P}$ levels (Table 1). Araújo \& Teixeira (2003) observed that $\mathrm{P}$ harvest index was relatively stable in nine bean cultivars in two distinct years while grain yield differed by $57 \%$, denoting that this index is an almost constant trait within each cultivar. Moreover, the lack of effect of varied soil P supply on harvest indices indicates that $\mathrm{P}$ nutrition did not alter the efficiency of remobilization of photoassimilates and $\mathrm{P}$ from leaves to seeds. Snapp \& Lynch (1996) also observed that P mobilization patterns from vegetative tissues were similar in common bean plants grown under low or high $\mathrm{P}$ supply, although leaf $\mathrm{P}$ remobilization seemed to have occurred earlier in low-P than in high-P plants.

It can be concluded that improved $\mathrm{P}$ nutrition did not modify the stage of maximal leaf production and the beginning of leaf senescence in common bean plants, but higher $\mathrm{P}$ supply stimulated leaf appearance and anticipated the stage of maximal leaf abscission. This seems to contradict the results of Grabau et al. (1986), who observed that exclusion of $\mathrm{P}$ from the nutrient solution advanced soybean leaf senescence compared to optimal nutrient level conditions. However, Grabau et al. (1986) induced different P treatments only during soybean seed development, and leaf senescence was evaluated by visual rating. By weekly measures of leaf appearance and loss, Snapp \& Lynch (1996) determined a lower leaf longevity in low-P than in high-P common bean plants, but the determinate cultivar Calima they used presented a negligible senesced leaf mass at a high applied $\mathrm{P}$ level. Crafts-Brandner (1992) suggested that $\mathrm{P}$ nutrition does not exert any regulatory control over leaf senescence, based on evidence that soil P levels that either depressed plant growth or enhanced leaf $\mathrm{P}$ concentration did not affect several traits related to senescence process. However, in the cited study, $\mathrm{P}$ treatments that did not differ regarding leaf senescence had similar leaf P concentrations (Crafts-Brandner, 1992), and perhaps the observed range of $P$ nutrition was narrow. Some of the contradictory results on the effects of $\mathrm{P}$ nutrition on leaf senescence of leguminous crops available in literature may be partially due to different experimental conditions.

What is the rationale behind the earlier maximal leaf decay of bean plants under optimal $\mathrm{P}$ supply, as compared with P-deficient plants? In the lack of evidence regarding the biochemical control of phosphate or even ATP, upon proteolytic activity during leaf senescence (Huffaker, 1990; Franklin \& Agren, 2002), a hypothesis can be defined based on source-sink relationships. Bean plants, particularly those with indeterminate growth habit, have a strong yield-component compensation and often great phenotypical plasticity (Kelly, 1998). Plants with improved growth and greater number of pods should therefore present a more intense seed filling and also advanced leaf senescence. A higher leaf shading inside a larger canopy can stimulate senescence of deeper leaves (Thomas \& Stoddart, 1980), but our experiment 
was carried out in widely spaced pots during SpringSummer, when self-shading was negligible. We did observe in field experiments that the grain maturity of bean plants under optimal $\mathrm{P}$ supply was advanced by a few days, compared with plants under low $\mathrm{P}$ supply, so leaf litter production began earlier in the growth cycle (Kubota, 2006); still, consistent results about the effects of $\mathrm{P}$ nutrition on the growth cycle duration of common bean crop are not available.

\section{CONCLUSION}

Soil $\mathrm{P}$ supply did not affect the stage of maximal leaf number and the beginning of leaf senescence of common bean plants, but the stage of greatest deposition of senesced leaves occurred earlier in the growth cycle as the soil $\mathrm{P}$ supply was raised.

\section{LITERATURE CITED}

AERTS, R. Nutrient resorption from senescing leaves of perennials: Are there general patterns? J. Ecol., 84:597608, 1996.

ARAÚJO, A.P. \& TEIXEIRA, M.G. Nitrogen and phosphorus harvest indices of common bean cultivars: Implications for yield quantity and quality. Plant Soil, 257:425-433, 2003.

ARAÚJO, A.P. \& TEIXEIRA, M.G. Ontogenetic variations on absorption and utilization of phosphorus in common bean cultivars under biological nitrogen fixation. Plant Soil, 225:1-10, 2000 .

CRAFTS-BRANDNER, S.J. Phosphorus nutrition influence on leaf senescence in soybean. Plant Physiol., 98:11281132,1992

EMPRESA BRASILEIRA DE PESQUISA AGROPECUÁRIA EMBRAPA. Centro Nacional de Pesquisa de Solos. Manual de métodos de análise de solo. 2.ed. Rio de Janeiro, Centro Nacional de Pesquisa de Solos, 1997. 212p.

FRANKLIN, O. \& AGREN, G.I. Leaf senescence and resorption as mechanisms of maximizing photosynthetic production during canopy development at $\mathrm{N}$ limitation. Funct. Ecol., 16:727-733, 2002.

GRABAU, L.J.; BLEVINS, D.G. \& MINOR, H.C. P nutrition during seed development. Leaf senescence, pod retention, and seed weight of soybean. Plant Physiol., 82:1008-1012, 1986.

HUFFAKER, R.C. Proteolytic activity during senescence of plants. New Phytol., 116:199-231, 1990.

KELLY, J.D.; KOLKMAN, J.M. \& SCHNEIDER, K. Breeding for yield in dry bean (Phaseolus vulgaris L.). Euphytica, 102:343-356, 1998.

KILLINGBECK, K.T. Nutrients in senesced leaves: Keys to the search for potential resorption and resorption proficiency. Ecology, 77:1716-1727, 1996.
KONDRACKA, A. \& RYCHTER, A.M. The role of $\mathrm{P}_{\mathrm{i}}$ recycling processes during photosynthesis in phosphate-deficient bean plants. J. Exp. Bot., 48:1461-1468, 1997.

KUBOTA, F.Y. Aumento do teor de fósforo e molibdênio em sementes de cultivares de feijoeiro via adubação foliar. Seropédica, Universidade Federal Rural do Rio de Janeiro, 2006. 81p. (Tese de Mestrado)

LIMA, E.R.; SANTIAGO, A.S.; ARAÚJO, A.P. \& TEIXEIRA, M.G. Effects of the size of sown seed on growth and yield of common bean cultivars of different seed sizes. Braz. J. Plant Physiol., 17:273-281, 2005.

LYNCH, J. \& RODRIGUEZ, H.N.S. Photosynthetic nitrogenuse efficiency in relation to leaf longevity in common bean. Crop Sci., 34:1284-1290, 1994.

LYNCH, J. \& van BEEM, J.J. Growth and architecture of seedling roots of common bean genotypes. Crop Sci., 33:1253-1257, 1993.

LYNCH, J. \& WHITE, J.W. Shoot nitrogen dynamics in tropical common bean. Crop Sci., 32:392-397, 1992.

MAKRIDES, S.C. \& GOLDTHWAITE, J. Biochemical changes during bean leaf growth, maturity, and senescence. J. Exp. Bot., 32:725-735, 1981.

MANRIQUE, L.A. Field bean leaf area development and seed yield as affected by phosphorus application on a Typic Tropudult in Panama. Comm. Soil Sci. Plant Anal., 17:135147, 1986.

MONDAL, W.A. \& CHOUDHURI, M.A. Comparison of phosphorus mobilization during monocarpic senescence in rice cultivars with sequential and non-sequential leaf senescence. Physiol. Plant., 65:221-227, 1985.

NETER, J.; WASSERMAN, W. \& KUTNER, M.H. Applied linear statistical models. 3.ed. Chicago, Richard D. Irwin, 1990. 1181p.

PHILLIPS, D.A.; PIERCE, R.O.; EDIE, S.A.; FOSTER, K.W. \& KNOWLES, P.F. Delayed leaf senescence in soybeans. Crop Sci., 24:518-522, 1984.

SESAY, A. \& SHIBLES, R. Mineral depletion and leaf senescence in soya bean as influenced by foliar nutrient application during seed filling. Ann. Bot., 45:47-55, 1980.

SNAPP, S.S. \& LYNCH, J.P. Phosphorus distribution and remobilization in bean plants as influenced by phosphorus nutrition. Crop Sci., 36:929-935, 1996.

STONE, L.F. \& PEREIRA, A.L. Sucessão arroz-feijão irrigados por aspersão: Efeitos de espaçamento entre linhas, adubação e cultivar no crescimento, desenvolvimento radicular e consumo d'água do feijoeiro. Pesq. Agropec. Bras., 29:939-954, 1994.

TEIXEIRA, M.G.; GUERRA, J.G.M.; ALMEIDA, D.L.; ARAÚJO, A.P. \& FRANCO, A.A. Effect of seed phosphorus concentration on nodulation and growth of three common bean cultivars. J. Plant Nutr., 22:15991611, 1999.

THOMAS, H. \& STODDART, J.L. Leaf senescence. Ann. Rev. Plant Physiol., 31:83-111, 1980. 